\title{
Identification of BACE1 cleavage sites in human voltage-gated sodium channel beta 2 subunit
}

\author{
Manuel T Gersbacher ${ }^{\dagger}$, Doo Yeon $\mathrm{Kim}^{\dagger}{ }^{\dagger}$, Raja Bhattacharyya, Dora M Kovacs ${ }^{* \dagger}$
}

\begin{abstract}
Background: The voltage-gated sodium channel $\beta 2$ subunit (Nav $\beta 2)$ is a physiological substrate of BACE1 ( $\beta$-site APP cleaving enzyme) and $\gamma$-secretase, two proteolytic enzymes central to Alzheimer's disease pathogenesis. Previously, we have found that the processing of Nav $\beta 2$ by BACE1 and $\gamma$-secretase regulates sodium channel metabolism in neuronal cells. In the current study we identified the BACE1 cleavage sites in human Nav $\beta 2$.

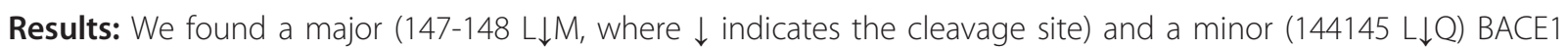
cleavage site in the extracellular domain of human Nav $\beta 2$ using a cell-free BACE1 cleavage assay followed by mass spectrometry. Next, we introduced two different double mutations into the identified major BACE1 cleavage site in human Nav $\beta 2: 147 \mathrm{LM} / \mathrm{NI}$ and 147LM/AA. Both mutations dramatically decreased the cleavage of human Nav $\beta 2$ by endogenous BACE1 in cell-free BACE1 cleavage assays. Neither of the two mutations affected subcellular localization of Nav $\beta 2$ as confirmed by confocal fluorescence microscopy and subcellular fractionation of cholesterol-rich domains. Finally, wildtype and mutated Nav 32 were expressed along BACE1 in B104 rat neuroblastoma cells. In spite of $\alpha$-secretase still actively cleaving the mutant proteins, Nav $\beta 2$ cleavage products decreased by $\sim 50 \%$ in cells expressing Nav $\beta 2$ (147LM/VI) and $~ 75 \%$ in cells expressing Nav $\beta 2$ (147LM/AA) as compared to cells expressing wildtype Nav $\beta 2$.

Conclusion: We identified a major (147-148 $L \downarrow M)$ and a minor (144-145 $L \downarrow Q)$ BACE1 cleavage site in human

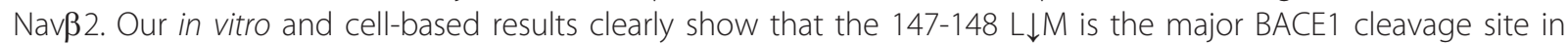
human Nav $\beta 2$. These findings expand our understanding of the role of BACE1 in voltage-gated sodium channel metabolism.
\end{abstract}

\section{Background}

BACE1/ $\beta$-secretase is an aspartic protease highly expressed in neuronal cells $[1,2]$. Together with presenilin $/ \gamma$-secretase, BACE1 cleaves the amyloid precursor protein (APP) to generate amyloid $\beta$ peptides $(A \beta)$. A $\beta$ accumulates in the brains of Alzheimer's disease patients where it promotes disease pathology [3,4]. In addition to contributing to $\mathrm{A} \beta$ generation, $\mathrm{BACE} 1$ regulates emotional memory, synaptic function and myelination in mouse brains possibly by cleaving multiple neuronal substrates [5-7]. More than 60 BACE1 substrates have recently been identified via quantitative proteomics [8]. However, only a few substrates have been investigated

\footnotetext{
* Correspondence: dora_kovacs@hms.harvard.edu

† Contributed equally

Neurobiology of Disease Laboratory, Genetics and Aging Research Unit, MassGeneral Institute for Neurodegenerative Disease, Massachusetts General Hospital, Harvard Medical School, Charlestown, MA 02129, USA
}

and confirmed in vivo [6,9-12]. Cleavage of substrate proteins may contribute to the important function of BACE1 in development and maintenance of the nervous system but the detailed molecular mechanism is not known.

Voltage-gated sodium channels (Nav) are composed of central $\alpha$ subunits and one or two accessory $\beta$ subunits [13]. The pore forming $\alpha$ subunits regulate sodium ion transport in neuronal membranes and are therefore essential for neuronal membrane excitability [13]. The $\beta$ subunits are type I transmembrane proteins with extracellular immunoglobulin and short intracellular C-terminal domains. Interaction of $\beta$ subunits with $\alpha$ subunits regulates Nav assembly and activity [13-15]. In particular, the $\beta 2$ subunit (Nav $\beta 2)$ regulates cell-surface expression and inactivation kinetics of Nav channels in neurons $[16,17]$. In addition, $\beta$ subunits modulate cell adhesion and neurite outgrowth [18-20].

\section{() Biomed Central}


Previously, we and another group found that ADAM10, BACE1, and $\gamma$-secretase cleave Nav $\beta 2$ in neuronal cells and mouse brains [11,12]. In a follow-up study, we showed that elevated BACE1 activity increased release of Nav $32-\mathrm{ICD}$ (intracellular domain) through cleavage of Nav $\beta 2$ resulting in elevated protein and mRNA levels of Nav1.1 $\alpha$ subunits in neuroblastoma cells [21,22]. Furthermore, processing of endogenous Nav $\beta 2$ and Nav1.1 protein levels were elevated in BACE1-transgenic mouse brains and eventually resulted in altered sodium current densities in hippocampal neurons. These data strongly suggest that BACE1 can regulate neuronal function, possibly by cleaving $N a v \beta 2$ in physiological conditions. In order to better understand the role of BACE1 in Nav metabolism, we have identified the BACE1 cleavage site in human $N a v \beta 2$ in the present study.

\section{Materials and methods}

\section{Plasmids, transfection, and reagents}

Expression constructs encoding full-length human Navß2 (GenBank: NM_004588) containing a C-terminal V5-His tag and full-length human BACE1 (GenBank: AF190725) containing a C-terminal myc tag have been described previously [11]. Nav $\beta 2$ (147LM/VI) and Nav $\beta 2$ (147LM/AA) were constructed using QuickChange Site-directed Mutagenesis kit (Stratagene) with the following primers: $\mathrm{Nav}_{2}$ (147LM/VI): 5'-GGCAAGATCCATCTGCAGGTCGTCATTGAAGAGCCCC CTGAGCGG-3' 5'-CCGCTCAGGGGGCTCTTCAATGACGACCTGCAGATGGATCTTGCC-3'; Navß2 (147 LM/AA): 5'-GGCAAGATCCATCTGCAGGTCGCCG CGGAAGAGCCCCCTGAGCGG-3' and 5-'CCGCTC AGGGGGCTCTTCCGCGGCGACCTGCAGATGGAT CTTGCC-3'. Effectene (Qiagen) was routinely used for transfecting cell lines. GL189 (Calbiochem) was used in $10 \mu \mathrm{M}$ concentration.

\section{In vitro cleavage assay of $\mathrm{Nav} \beta 2$ substrate peptide}

Nav $\beta 2$ substrate peptide ( $\beta 2$-peptide) with $\mathrm{N}$-terminal biotin was synthesized by CHI Scientific (M.W. 4049.7, purity $=94.02 \%$ determined by HPLC). A biotinylated tyrosine group was added to the $\mathrm{N}$-terminus of the $\beta 2$-peptide. Reaction mixtures containing $20 \mathrm{mg}$ of $\beta 2$-peptide, $0.1 \mathrm{M} \mathrm{Na}$-Acetate ( $\mathrm{pH} 4.0$ ), and $2.5 \mathrm{mg}$ human BACE1 (R\&D systems), were prepared and incubated at $37^{\circ} \mathrm{C}$ for $16 \mathrm{~h}$. Reactions were stopped by heating to $95^{\circ} \mathrm{C}$ with LDS-SDS-PAGE sample loading buffer (Invitrogen) for $5 \mathrm{~min}$.

Reaction samples were then resolved on $12 \%$ BisTris gels (Invitrogen), transferred to PDVF membrane for Western blot analysis or fixed directly for silver staining. Vector ABC kit (Vector Labs) was used to detect fulllength and $\mathrm{N}$-terminal fragment of $\beta 2$-peptide in
Western Blot while Silver SNAP II kit (Invitrogen) was used to detect total protein in the gel.

\section{Mass spectrometry}

Reaction samples from the $\beta 2$-peptide in vitro cleavage assay were analyzed by MS using a QStarR Pulsar I (Applied Biosystems) equipped with a nanospray source (in collaboration with Proteomic core at Harvard Partners Center for Genetics and Genomics). Analyst software (Invitrogen) was used to determine the molecular weights of all cleavage products in the reaction mixture.

\section{Western blot analysis}

Cell lysates were prepared by directly extracting cells in a buffer containing $10 \mathrm{mM}$ Tris- $\mathrm{HCl}(\mathrm{pH} 6.8), 1 \mathrm{mM}$ EDTA, $150 \mathrm{mM} \mathrm{NaCl}, 0.25 \%$ Nonidet P-40, 1\% Triton $\mathrm{X}-100$, and a protease inhibitor cocktail (Roche) followed by a centrifugation at $16,000 \mathrm{~g}$. 20-50 mg of protein were resolved on $12 \%$ BisTris gels (Invitrogen). The blots were visualized by enhanced chemiluminescence (ECL). Images were captured using BioMax film (Kodak) or VersaDoc imaging system (Biorad) and quantified with QuantityOne software (Biorad). The followings are antibodies used in this study: anti-V5 (1:5000; Invitrogen), anti-myc (1:2000: Cell Signalling) anti-GAPDH (1:2000; BD Biosciences), and antiflotillin1 (1:250; BD Biosciences).

\section{In vitro generation of $\mathrm{Nav} \beta 2-\mathrm{CTF} \beta$}

Membrane preparation and in vitro generation of Nav $\beta 2$-CTF $\beta$ were performed as described earlier [23]. In brief, cells were washed with PBS, scraped in $1 \mathrm{ml}$ PBS and centrifuged for min at $8000 \mathrm{rpm}$. Cell pellets were resuspended in $700 \mu \mathrm{l}$ buffer $\mathrm{H}$ (20 mM HEPES, $150 \mathrm{mM} \mathrm{NaCl}, 10 \%$ glycerol, $5 \mathrm{mM}$ EDTA, pH 7.4) and the solution drawn 20 times through a $3 \mathrm{ml}$ syringe with 20 gauge needle. Unbroken cells were removed by centrifugation at $4000 \mathrm{rpm}$ for $5 \mathrm{~min}$. In order to obtain P2 fractions, the supernatant was centrifuged at 55000 $\mathrm{rpm}$ for $1 \mathrm{~h}$ and $4^{\circ} \mathrm{C}$. Membrane fractions were washed once in $300 \mu \mathrm{l}$ incubation buffer $(0.1 \mathrm{M} \mathrm{Na}$ Acetate $\mathrm{pH}$ 4.0, $10 \mu \mathrm{g} / \mathrm{ml}$ Leupeptin, $1 \mu \mathrm{g} / \mathrm{ml}$ Aprotinin, $1 \mathrm{mM}$ PNT and $5 \mathrm{mM}$ EDTA) and resuspended in $100 \mu$ incubation buffer in absence or presence of GL189. After incubation for $3 \mathrm{~h}$ at either $0^{\circ} \mathrm{C}$ or $37^{\circ} \mathrm{C}$, the samples were loaded on $12 \%$ BisTris and investigated by Western blot analysis.

\section{Lipid Raft Fractionation}

Cells were grown to $80-90 \%$ confluency in three 150-mm dishes, washed twice in phosphate buffered saline and scraped into $1.2 \mathrm{ml}$ extraction buffer containing 0.5\% Lubrol WX (Lubrol 17A17; Serva), protease inhibitor cocktail (Roche) and $1 \mathrm{mM}$ phenylmethylsulfonyl 
fluoride (PMSF). Cells were then homogenized by five passages through a 25 -gauge needle. Cell lysates were adjusted to $45 \%$ final concentration of sucrose (final volume, $4 \mathrm{ml}$ ) and loaded to the bottom of a $12-\mathrm{ml}$ SW41 ultracentrifuge tube. A discontinuous sucrose gradient was established by sequentially layering 35\% sucrose $(4 \mathrm{ml})$ and $5 \%$ sucrose $(4 \mathrm{ml})$ on top of the sample. Tubes were subjected to ultracentrifugation at $39,000 \mathrm{rpm}$ for $18 \mathrm{~h}$ in Beckman SW 41 rotor at $4^{\circ} \mathrm{C}$. Twelve $1 \mathrm{ml}$ fractions were collected from the top of the gradient and equal volume of each fraction was analyzed by Western blotting. V5 antibody was used to detect Navß2 and flotillin-1 antibody was used as a lipid raft marker.

\section{Immunocytochemistry}

Cells were grown on coverslips to $20-40 \%$ confluency and fixed with $4 \%$ paraformaldehyde for $20 \mathrm{~min}$ at room temperature. Cells were then rinsed three times with PBS and blocked for $1 \mathrm{~h}$ in PBS containing 1\% BSA (Sigma-Aldrich) 0.1\% Triton X-100 (FisherBiotech), 0.1\% Gelatin (Sigma-Aldrich) and 0.05\% Tween 20 (MP Biomedicals). Cells were incubated with anti V5 antibody for $1 \mathrm{~h}$, washed three times with PBS and incubated for 30 min with rabbit anti-mouse Alexa Fluor 488 antibody (1:200: Serotec) at room temperature. After washing three times with PBS containing $0.1 \%$ Triton X-100 and 0.05\% Tween-20 for 3 min the coverslips were mounted onto glass slides using Prolong Gold antifade reagent with DAPI (Invitrogen) and analyzed with a Olympus florescence microscope equipped with a confocal disk scanning unit.

\section{Results}

Identification of BACE1 cleavage sites in human Nav $\beta 2$

To identify BACE1 cleavage sites in human Nav $\beta 2$, we synthesized a substrate peptide ( $\beta 2$-peptide) corresponding to a 32 amino acid sequence at the juxtamembrane region of human $\operatorname{Nav} \beta 2$ (Figure 1D). A biotinylated tyrosine group was added to the N-terminus of the $\beta 2$-peptide to detect $\mathrm{N}$-terminal fragments. Reaction mixtures containing the $\beta 2$ peptide and purified recombinant human BACE1 were incubated at $37^{\circ} \mathrm{C}$ for $16 \mathrm{~h}$. The incubation of the $\beta 2$-peptide with BACE1 specifically increased cleavage products $\sim 2 \mathrm{kDa}$, detected by both silver staining and anti-biotin-HRP conjugate (Figure 1A and $1 \mathrm{~B}$, lane \#2). The generation of the $2 \mathrm{kDa}$ cleavage products was dramatically inhibited by the BACE1 inhibitor GL-189 (Figure 1A and 1B, lane \#3). The reaction samples were then analyzed by mass spectrometry (MS) to characterize all cleavage products (Figure 1C). Thus we were able to identify a major (147-148 $\mathrm{L} \downarrow \mathrm{M}$, where $\downarrow$ indicates the cleavage site) and a minor (144-145 L $\downarrow$ Q)
BACE1 cleavage site in the extracellular domain of human Nav $\beta 2$ (Figure 1D). Interestingly, we found that the major cleavage site of human Nav $\beta 2$ is slightly different from the one previously reported for mouse Navß2 (Figure five, [12]). This difference might be due to two amino acid changes, $143(\mathrm{H} / \mathrm{Y})$ and $148(\mathrm{M} / \mathrm{L})$ close to the known BACE1 cleavage sites in human and mouse $\operatorname{Nav} \beta 2$.

\section{Mutations of the BACE1 cleavage site decrease BACE1- mediated processing of human $\mathrm{Nav} \beta 2$ in purified $\mathrm{CHO}$ cells membrane}

To specifically measure BACE1-mediated cleavage of $N a v \beta 2$, we used a cell-free BACE1-cleavage assay [21]. We introduced two separate double mutations, 147LM/VI and 147LM/AA at the S1 and S1' positions of the major BACE1 cleavage site (Figure 2A). Wildtype and mutated human $N a v \beta 2$ were expressed in $\mathrm{CHO}$ cells and crude membrane fractions prepared from those cells were incubated for $3 \mathrm{~h}$ at $\mathrm{pH} 4.5$ with or without the BACE1 inhibitor GL-189. As expected, wildtype $\operatorname{Nav} \beta 2$ (WT) was cleaved at $37^{\circ} \mathrm{C}$ to generate $\beta 2-C T F \beta$, which is completely blocked by treatment with GL-189 (Figure 2B, left panel). However, the cleavage of $N a v \beta 2(147 \mathrm{LM} / \mathrm{VI})$ and $N a v \beta 2$ (147LM/ AA) is dramatically decreased (Figure $2 \mathrm{~B}$, middle and right panel). These data strongly indicate that 147-148 $\mathrm{L} \downarrow \mathrm{M}$ is the major BACE1 cleavage site in human $\operatorname{Nav} \beta 2$.

\section{Mutations of the BACE1 cleavage site do not affect subcellular localization of human $\operatorname{Nav} \beta 2$}

To exclude the possibility that the mutations introduced into Nav $\beta 2$ caused its retention in early compartments, we studied the subcellular localization of the mutated versus wildtype Nav $\beta 2$. We established enriched cultures of $\mathrm{CHO}$ cells transfected with wildtype and mutated Nav $\beta 2$ and investigated localization of Nav $\beta 2$ by florescence confocal microscopy. We could not detect any significant difference in the subcellular localization of mutated $N a v \beta 2$ as compared to wildtype $N a v \beta 2$ (Figure 3A). These data were also confirmed in B104 cells (data not shown).

Next, we tested whether the distribution of $\operatorname{Nav} \beta 2$ into cholesterol-rich domains (lipid rafts) is altered by the 147LM/AA mutation. As previously reported, Nav $\beta 2$ was detected in lipid raft enriched fractions, confirmed by flotillin-1 staining (Figure 3B, fractions 2 to 4, [12]). We could not detect any significant changes in the levels of $\mathrm{Nav} \beta 2$ (147LM/AA) in lipid-raft fractions. Together, these results suggest that localization of Nav $\beta 2$ was not affected by mutations of the BACE1 cleavage site. 
A

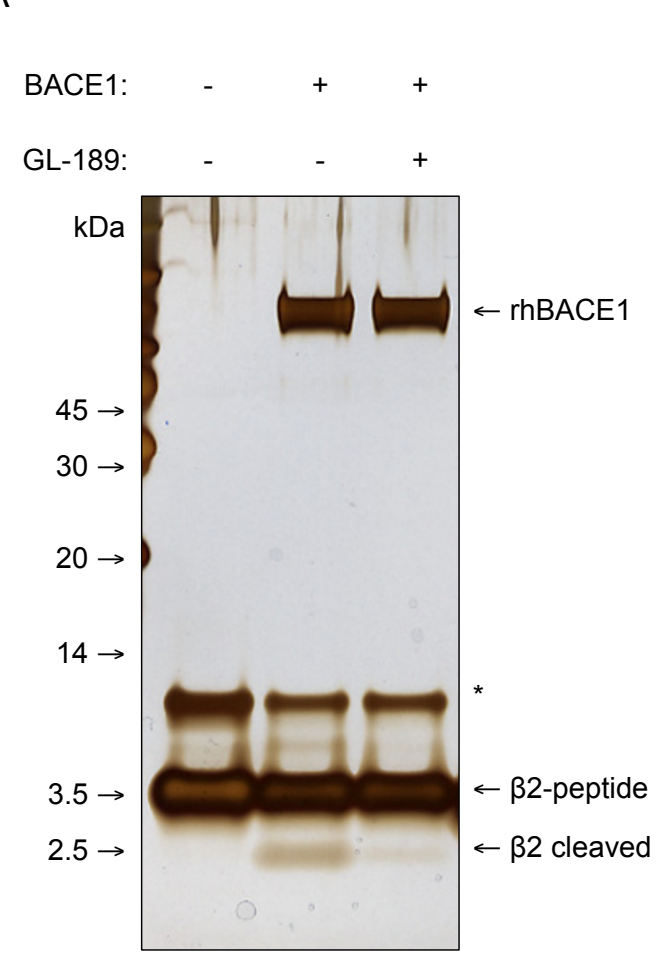

B

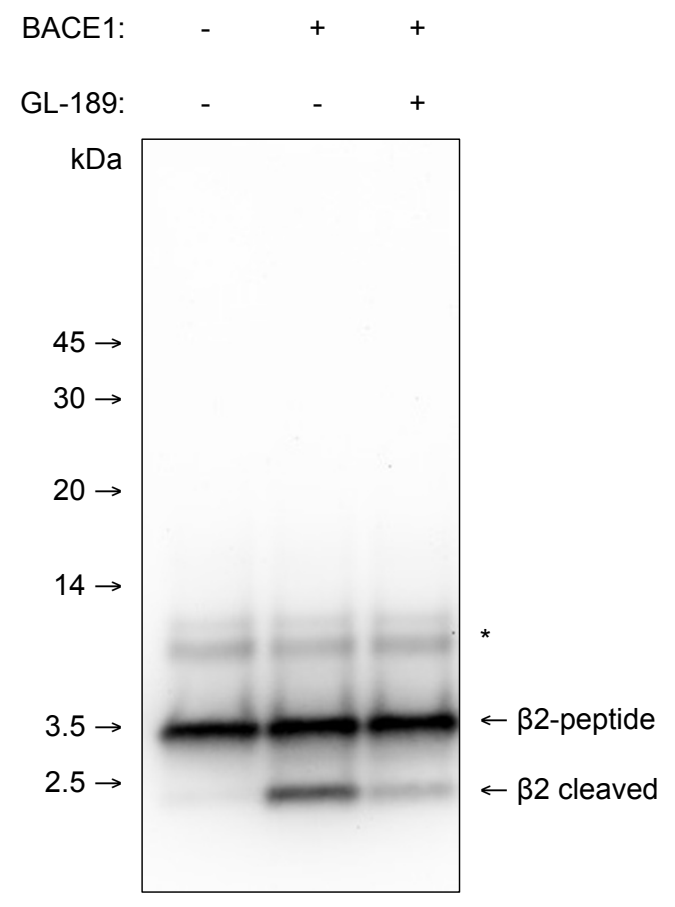

C

\begin{tabular}{|c|c|c|c|c|c|}
\hline aa1 & sequence & $\mathbf{z}$ & PepMW & $\beta 2$-peptide & $\begin{array}{c}\text { B2-peptide } \\
\text { +BACE1 }\end{array}$ \\
\hline 128 & (226.0713)YLMNPPDRHRGHGKLHL & 3 & 2267.138 & & 3880000 \\
\hline 128 & (226.0713)YLMNPPDRHRGHGKLHLQVL & 2 & 2607.349 & & 1980000 \\
\hline 128 & (226.0713)YLMNPPDRHRGHGKLHLQVL & 3 & 2607.349 & & 45400000 \\
\hline 128 & (226.0713)YLMNPPDRHRGHGKLHLQVL & 4 & 2607.349 & & 10800000 \\
\hline 128 & (226.0713)YLMNPPDRHRGHGKLHLQVLMEEPPERDSTVAV & 3 & 4048.005 & 13700000 & 22300000 \\
\hline 128 & (226.0713)YLMNPPDRHRGHGKLHLQVLMEEPPERDSTVAV & 4 & 4048.005 & 84200000 & 104000000 \\
\hline 145 & QVLMEEPPERDSTVAV & 2 & 1799.885 & & 1320000 \\
\hline 148 & MEEPPERDSTVAV & 2 & 1459.674 & & 24700000 \\
\hline
\end{tabular}

D

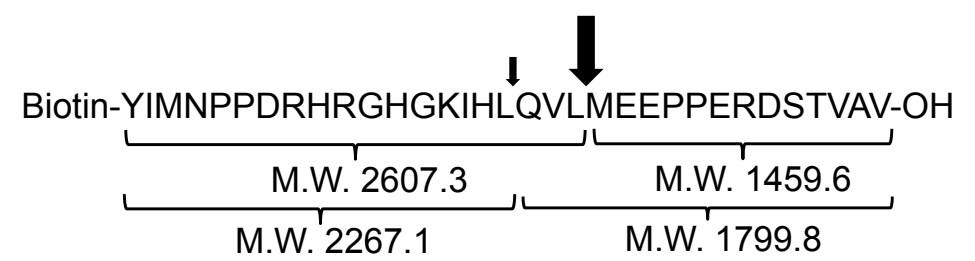

Figure 1 Identification of BACE1 cleavage sites in human Nav $\beta 2$ by MS analysis. Reaction mixtures from an in vitro BACE1 cleavage assay were resolved on a 12\% BisTris gel and full-length peptide and cleavage products were detected by silver staining. Only the incubation of the $\beta 2$-peptide with BACE1 generates a 2 kDa cleavage product. GL-189, a BACE1 inhibitor, significantly decreased the amount of cleavage product (lane 3). B) Western blot analysis of an in vitro BACE1 cleavage assay samples using anti-biotin-HRP conjugate. C) Table containing the major cleavage products and their predicted sequences determined by Mass spectrometry from control and the BACE1 reaction sample. D) Sequence of the $\beta 2$-peptide synthesized for the in vitro cleavage assay. A biotinylated tyrosine amino acid is added to the N-terminus of the peptide for detection by anti-biotin-HRP conjugate. One major (big arrow) and one minor (small arrow) BACE1 cleavage site were detected by MS analysis. 


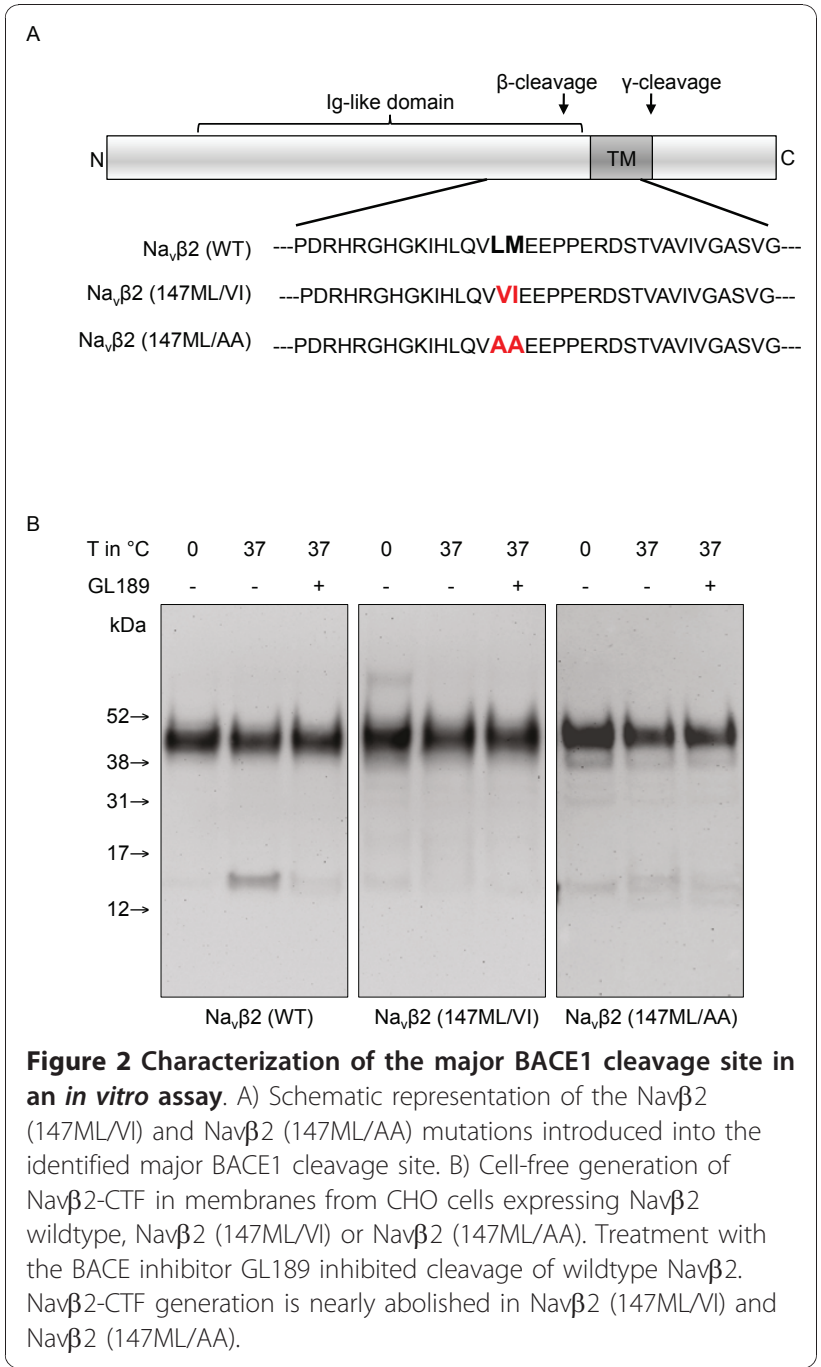

\section{Mutations of the BACE1 cleavage site decrease processing in cell based models}

To further investigate the identified major BACE1 cleavage site (147-148 $\mathrm{L} \downarrow \mathrm{M})$, we tested whether 147LM/VI and $147 \mathrm{LM} / \mathrm{AA}$ mutations would also reduce Nav $\beta 2$ cleavage in cells. Wildtype and mutated Nav $\beta 2$ were transfected into B104 rat neuroblastoma cells stably overexpressing BACE1. $\alpha$-secretase-mediated processing of Nav $\beta 2$ would not be affected by mutations in the BACE1 cleavage site. Therefore, we did not expect complete inhibition of Nav $\beta 2$ processing in cells expressing the mutated form of the protein. Indeed, we found that Nav $\beta 2$-CTF production was decreased by $~ 50 \%$ in cells expressing Nav $\beta 2$ (147LM/VI) and reduced by $\sim 75 \%$ in cells expressing NavB2 (147LM/AA) as compared to wildtype Nav $\beta 2$ expressing cells (Figure 4A and 4B). In addition, we transfected wildtype $N a v \beta 2$ and Nav $\beta 2$ (147LM/VI) together with BACE1 into CHO cells. Similar to B104 cells, mutation of the identified BACE cleavage site strongly reduced Nav $\beta 2$-CTF production (data not shown). These data confirm that 147-148 L $\downarrow$ $\mathrm{M}$ is the major BACE1 cleavage site in human Nav $\beta 2$.

\section{Discussion}

Using a similar synthetic peptide substrate and MALDI-

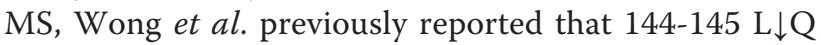
is the major BACE1 cleavage site of mouse Nav $\beta 2$ [12]. It is interesting that the major cleavage site of human $\mathrm{Nav} \beta 2$ is slightly different from that of mouse Nav $\beta 2$ (Figure 1D and 5). The mouse BACE1 cleavage site of Nav $\beta 2$ is similar to the minor (144-145 L $\downarrow$ Q) BACE1 cleavage site in the human $N a v \beta 2$ identified in our study. This site difference may be due to amino acid differences between human and mouse Nav $\beta 2$. As shown in Figure 5 there are two amino acid changes between human and mouse, in proximity to the BACE1 cleavage sites Navß2 (143(H/Y) and 148(M/L)). Particularly, the $148(\mathrm{M} / \mathrm{L})$ site is located in the $\mathrm{S} 1$ ' position of the BACE1 cleavage site of human Nav $\beta 2$. According to Turner et al., a methionine at S1' position in human $\mathrm{Nav} \beta 2$ is highly preferable for BACE1 cleavage as compared to a leucine [24]. Further studies will be required to confirm this cleavage site in brains and to explain whether changes in the BACE1 cleavage site between species would lead to a differential regulation of sodium channel metabolism in human as compared to mouse.

A recent study identified 68 BACE1 substrates, underscoring the role of BACE1 in various cellular processes [8]. Similarly to Nav $\beta 2$, the majority of those substrates are, type 1 transmembrane proteins with extracellular $\mathrm{N}$-terminal and intracellular C-terminal ends. However, in addition to Nav $\beta 2$ only a few BACE1 substrates have been confirmed under physiological conditions. These include APP, Neuregulin 1/3 (NRG-1/3), alpha 2,6-sialyltransferase (ST6GAL1), and P-selectin glycoprotein ligand-1 (PSGL1) $[6,912]$. As shown in Figure 5 the BACE1 cleavage sites in these substrates show highly similar sequences. For example, the S1 cleavage position has been suggested as the most important site for determining BACE1-mediated processing based on an in vitro cleavage assay using synthetic substrate peptides [24]. The majority of substrates harbor leucine, phenylalanine, or methionine at the S1 cleavage site. Interestingly, human Nav $\beta 2$ harbors both leucine and methionine at the S1 and S1' position, which are the most preferable residues at those positions according to in vitro studies [24]. These studies also suggest, that subsites proximal to the scissile bond (S1 and S'1) are more stringent than distal residues which is reflected by the drastic decrease in CTF production in Nav $\beta 2$ harboring mutations 147LM/AA or 147LM/VI.

In our previous studies, we have found that elevated BACE1-mediated cleavage of human Nav $\beta 2$ increased 
A
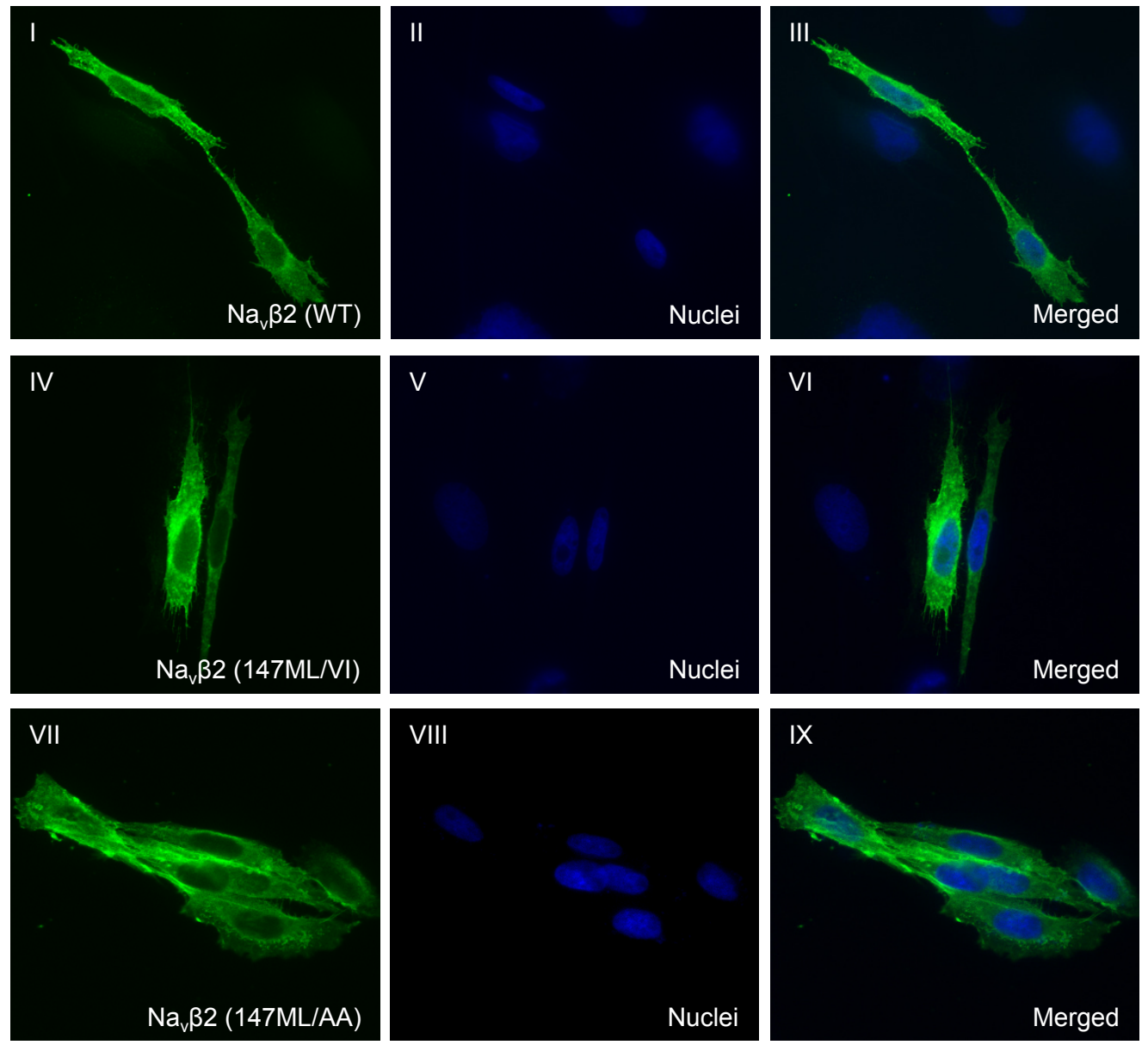

B
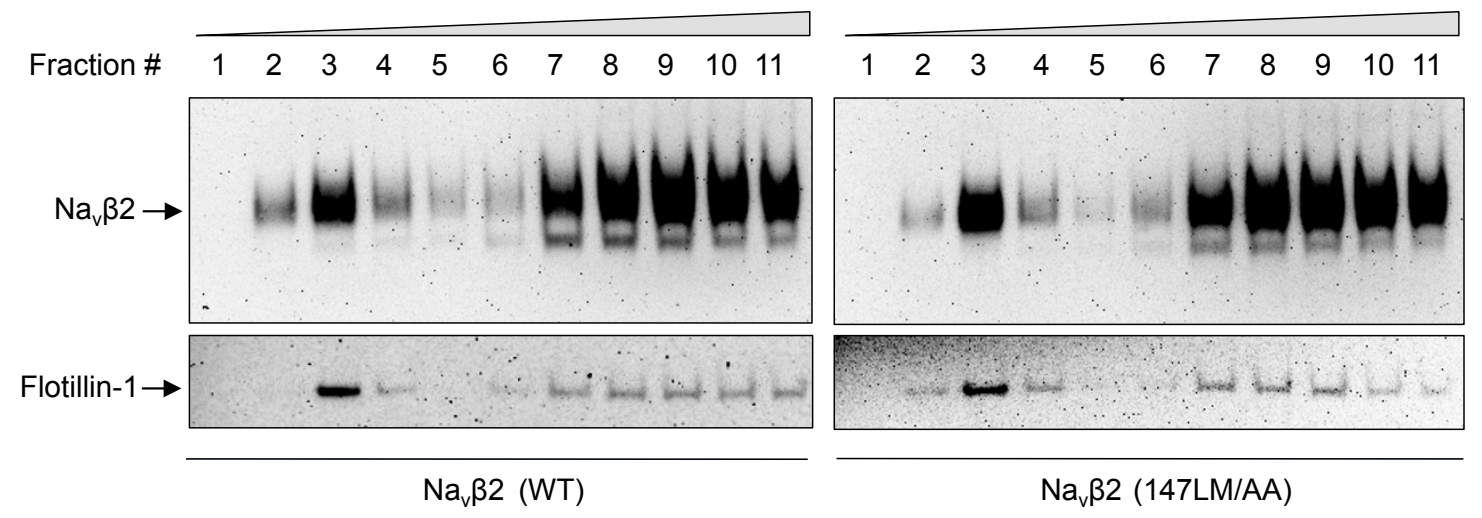

Figure 3 Similar subcellular localizations of $\operatorname{Nav} \beta 2(147 \mathrm{LM} / \mathrm{VI})$ and $\operatorname{Nav} \beta 2$ (147LM/AA) as compared to wildtype Nav $\beta 2$. A) Confocal images of enriched cultures expressing Nav $\beta 2$ wildtype, Nav $\beta 2$ (147ML/NI) or Nav $\beta 2$ (147ML/AA) immunostained with a C-terminal V5 antibody. B) Western blot analysis of cells expressing either wildtype Nav $\beta 2$ or Nav $\beta 2$ (147LM/AA) subjected to sucrose gradient fractionation. Flotillin-1 staining marks lipid raft fractions. The Nav $32(147 \mathrm{ML} / \mathrm{NI})$ and $\operatorname{Nav} \beta 2$ (147ML/AA) mutations in the BACE1 cleavage site did not visibly affect subcellular or lipid raft localization of Nav 32 . 


$$
\text { A }
$$

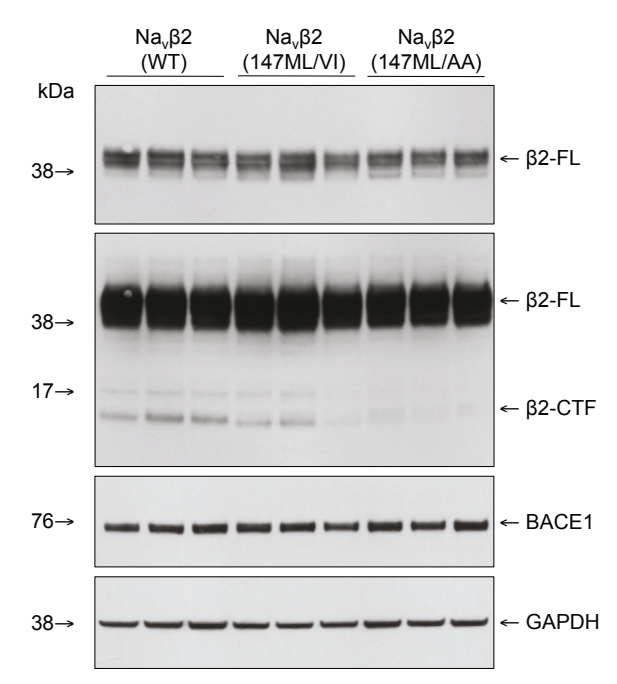

B

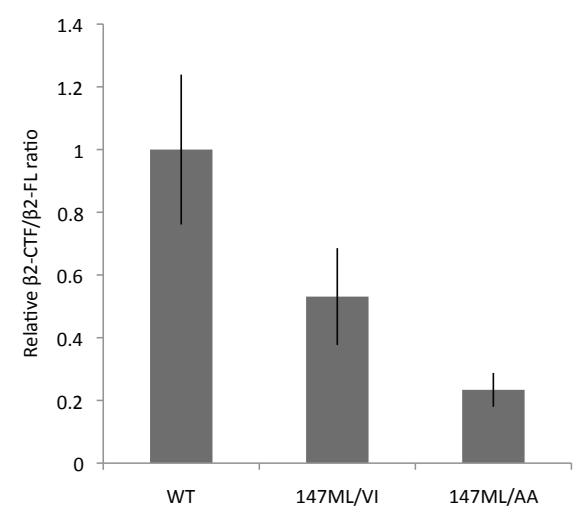

Figure 4 Mutations in the BACE1 cleavage site strongly decrease processing of Nav $\beta 2$ in B104 cells overexpressing BACE1. A) B104 cells stably overexpressing BACE1 were transfected with Nav $\beta 2$ wild-type, $\operatorname{Nav} \beta 2$ (147ML/NI) or Nav $\beta 2$ (147ML/AA) and then subjected to Western blot analysis. B) Quantification of Nav $\beta 2-$ CTF to Nav $\beta 2-F L$ ratios from $A$. Nav $\beta 2-C T F$ levels were decreased by mutations in the BACE1 cleavage site ( $F L$, full length; $C T F, C$-terminal fragment).
mRNA and protein levels of Nav1.1 $\alpha$ subunit by increasing the release of the $\beta 2$ intracellular domain (Navß2-ICD) [21]. Therefore, it will be interesting to see whether the blockage of BACE1 cleavage in Nav $\beta 2$ 147LM/IV and Nav $\beta 2147$ LM/AA would also decrease Nav1.1 levels by decreasing Nav $\beta 2$-CTF levels and possibly Nav $\beta 2-I C D$ levels. However, these studies are difficult because $\alpha$-secretase cleavage of Nav $\beta 2$ is not affected by the 147 LM/VI and 147 LM/AA mutations. On the contrary, we have observed elevated $\alpha$-secretase cleavage in $\mathrm{CHO}$ cells transiently expressing Nav $\beta 2$ (147 (LM/AA) (data not shown). The $\alpha$-secretase cleavage site is distinct from and closer to the membrane than the BACE1 cleavage site, unlikely to be directly affected by the BACE1 cleavage site mutations [21,25]. It is more likely that the elevated $\alpha$-secretase cleavage observed only in $\mathrm{CHO}$ cells is due to a compensatory asecretasemediated cleavage since BACE1 and $\alpha$-secretase seem to compete for juxtamembrane cleavages as shown in APP processing. Additional mutations completely blocking $\alpha$ secretase-mediated cleavages will be required to fully address the role of BACE1 in sodium channel metabolism in normal conditions.

BACE1 levels and activities are significantly elevated in $\mathrm{AD}$ brains, possibly contributing to the disease progression [26-28]. BACE1 levels are also increased in some injury conditions including brain trauma [29] and ischemia [30-32], suggesting a possible role of BACE1 as a stress-response protein [2]. The fact that BACE1 regulates Nav channel metabolism via $N a v \beta 2$ suggests the interesting possibility that BACE1 might modulate sodium channel metabolism not only in AD but also in other disease conditions in which BACE1 levels are increased. It will be interesting to test whether the BACE1cleavage mutation in $\operatorname{Nav} \beta 2$ reported here would also alter sodium channel metabolism in various stress conditions including oxidative stress and mitochondrial dysfunctions, which are known to increase BACE1 levels.

\begin{tabular}{|c|c|c|c|c|c|c|c|c|c|c|c|c|c|c|}
\hline & & & & S4 & S3 & S2 & s1 & S1' & S2' & S3' & S4' & & & \\
\hline $\mathrm{Na}_{\mathrm{v}} \boldsymbol{\beta} \mathbf{2}$ & $\mathrm{K}$ & 1 & $\mathrm{H}$ & $\mathrm{L}$ & $Q$ & $\mathrm{~V}$ & $\mathrm{~L}$ & $M$ & $E$ & $E$ & $P$ & $P$ & $\mathrm{E}$ & $\mathrm{R}$ \\
\hline $\mathrm{Na}_{\mathrm{v}} \beta 2$ (mouse) & G & $\mathrm{H}$ & G & $\mathrm{K}$ & 1 & Y & L & Q & v & L & L & $\mathrm{E}$ & $\mathrm{E}$ & $\mathrm{P}$ \\
\hline APP & $E$ & 1 & $S$ & $E$ & V & K & M & $\mathrm{D}$ & A & $E$ & $\mathrm{~F}$ & $\mathrm{R}$ & $\mathrm{H}$ & $\mathrm{D}$ \\
\hline APP (Swedish) & $\mathrm{E}$ & 1 & $\mathrm{~s}$ & $\mathrm{E}$ & V & $\mathrm{N}$ & $\mathrm{L}$ & D & A & $\mathrm{E}$ & $\mathrm{F}$ & $\mathrm{R}$ & $\mathrm{H}$ & $\mathrm{D}$ \\
\hline NRG1 & $\mathrm{K}$ & $\mathrm{H}$ & $\mathrm{L}$ & G & I & E & $\mathrm{F}$ & M & $\mathrm{E}$ & A & $\mathrm{E}$ & $\mathrm{E}$ & $\mathrm{L}$ & $\mathrm{Y}$ \\
\hline ST6GAL1 & $\mathrm{D}$ & Y & E & $A$ & L & $\mathrm{T}$ & L & Q & A & $\mathrm{K}$ & E & $\mathrm{F}$ & Q & $\mathrm{M}$ \\
\hline PSGL1 & $\mathrm{K}$ & Q & A & A & $\mathrm{s}$ & $\mathrm{N}$ & 1 & $\mathrm{~s}$ & $\mathrm{~V}$ & $\mathrm{~N}$ & $Y$ & $\mathrm{P}$ & $\mathrm{V}$ & G \\
\hline
\end{tabular}

Figure 5 Cleavage sequence comparison among BACE1 substrates. A black arrow indicates the currently characterized BACE1 cleavage sites of BACE1 substrates. Amino acid preferences around the BACE1 cleavage sites were determined by Turner R.T. et al. [24]. Interestingly, human Nav $\beta 2$ harbors the preferable residues at S1 and S1', the most important positions for BACE1 recognition and cleavage. 


\section{Conclusion}

We identified a major (147-148 $\mathrm{L} \downarrow \mathrm{M})$ and a minor (144$145 \mathrm{~L} \downarrow \mathrm{Q})$ BASE1 cleavage site in human Nav $\beta 2$ by using a synthetic $\beta 2$-peptide and MS. We also found that mutations of the major BACE1 cleavage site (147LM/VI and 147 LM/AA) dramatically decreased BACE1mediated cleavage of human $N a v \beta 2$ in an in vitro assay and a cell based model. Our data clearly demonstrate that the BACE1 cleavage site (147-148 $\mathrm{L} \downarrow \mathrm{M})$ is mainly responsible for BACE1 cleavage of human Nav $\beta 2$.

\section{Abbreviations used}

APP: amyloid precursor protein; A $\beta$ : amyloid $\beta$ peptide; Nav: voltage-gated sodium channel; MS: mass spectrometry; Nav $\beta 2$ : voltage-gated sodium channel $\beta 2$ subunit; BACE1: $\beta$-site APP cleaving enzyme; $\beta 2$-peptide: Nav $\beta 2$ substrate peptide; $\mathrm{CHO}$ : Chinese hamster ovary; CTF: C-terminal fragment; FL: full-length; ICD: intracellular domain

\section{Acknowledgements}

We would like to thank Drs. Aleister Saunders (Drexel University) and Rudolph E. Tanzi (Massachusetts General Hospital/Harvard Medical School) for the human BACE1 construct. This work is supported by grants from the $\mathrm{NIH} / \mathrm{NIA}$

\section{Authors' contributions}

MTG and DYK participated in the design of the study and drafted the manuscript. MTG carried out the in vitro cleavage assay, immunofluorescence imaging and Western blotting. DYK did the in vitro cleavage assay and MS. RB carried out the lipid raft fractionation and helped to draft the manuscript. DMK conceived of the study, participated in its design and coordination and helped to draft the manuscript. All authors read and approved the final manuscript.

\section{Competing interests}

The authors declare that they have no competing interests.

Received: 11 November 2010 Accepted: 23 December 2010 Published: 23 December 2010

\section{References}

1. Vassar R: BACE1: the beta-secretase enzyme in Alzheimer's disease. $J \mathrm{Mol}$ Neurosci 2004, 23:105-114.

2. Cole SL, Vassar R: The Alzheimer's disease beta-secretase enzyme, BACE1. Mol Neurodegener 2007, 2:22.

3. Hardy J, Selkoe DJ: The amyloid hypothesis of Alzheimer's disease: progress and problems on the road to therapeutics. Science 2002, 297:353-356.

4. Selkoe DJ: Alzheimer's disease is a synaptic failure. Science 2002, 298:789-791.

5. Laird FM, Cai H, Savonenko AV, Farah MH, He K, Melnikova T, Wen H, Chiang $\mathrm{H}-\mathrm{C}, \mathrm{Xu}$ G, Koliatsos VE, et al: BACE1, a major determinant of selective vulnerability of the brain to amyloid-beta amyloidogenesis, is essential for cognitive, emotional, and synaptic functions. I Neurosci 2005, 25:11693-11709.

6. Willem M, Garratt AN, Novak B, Citron M, Kaufmann S, Rittger A, DeStrooper B, Saftig P, Birchmeier C, Haass C: Control of peripheral nerve myelination by the beta-secretase BACE1. Science 2006, 314:664-666.

7. Hu X, Hicks CW, He W, Wong P, Macklin WB, Trapp BD, Yan R: Bace1 modulates myelination in the central and peripheral nervous system. Nat Neurosci 2006, 9:1520-1525

8. Hemming ML, Elias JE, Gygi SP, Selkoe DJ: Identification of beta-secretase (BACE1) substrates using quantitative proteomics. PLOS ONE 2009, 4 : e8477.

9. Kitazume S, Tachida Y, Oka R, Kotani N, Ogawa K, Suzuki M, Dohmae N, Takio K, Saido TC, Hashimoto Y: Characterization of alpha 2,6- sialyltransferase cleavage by Alzheimer's beta secretase (BACE1). J Biol Chem 2003, 278:14865-14871.

10. Lichtenthaler SF, Dominguez D-I, Westmeyer GG, Reiss K, Haass C, Saftig P, De Strooper B, Seed B: The cell adhesion protein P-selectin glycoprotein ligand-1 is a substrate for the aspartyl protease BACE1. J Biol Chem 2003, 278:48713-48719.

11. Kim DY, Ingano LAM, Carey BW, Pettingell WH, Kovacs DM: Presenilin/ gamma-secretase-mediated cleavage of the voltage-gated sodium channel beta2-subunit regulates cell adhesion and migration. J Biol Chem 2005, 280:23251-23261.

12. Wong H-K, Sakurai T, Oyama F, Kaneko K, Wada K, Miyazaki H, Kurosawa M, De Strooper B, Saftig P, Nukina N: beta Subunits of voltage-gated sodium channels are novel substrates of beta-site amyloid precursor proteincleaving enzyme (BACE1) and gamma-secretase. J Biol Chem 2005, 280:23009-23017.

13. Catterall WA: From ionic currents to molecular mechanisms: the structure and function of voltage-gated sodium channels. Neuron 2000, 26:13-25.

14. Isom LL: Sodium channel beta subunits: anything but auxiliary. Neuroscientist 2001, 7:42-54

15. Yu FH, Westenbroek RE, Silos-Santiago I, McCormick KA, Lawson D, Ge P, Ferriera H, Lilly J, DiStefano PS, Catterall WA, et al: Sodium channel beta4, a new disulfide-linked auxiliary subunit with similarity to beta2. J Neurosci 2003, 23:7577-7585.

16. Chen C, Bharucha V, Chen Y, Westenbroek RE, Brown A, Malhotra JD, Jones D, Avery C, Gillespie PJ, Kazen-Gillespie KA, et al: Reduced sodium channel density, altered voltage dependence of inactivation, and increased susceptibility to seizures in mice lacking sodium channel beta 2-subunits. Proc Natl Acad Sci USA 2002, 99:17072-17077.

17. Lopez-Santiago LF, Pertin M, Morisod X, Chen C, Hong S, Wiley J, Decosterd I, Isom LL: Sodium channel beta2 subunits regulate tetrodotoxin-sensitive sodium channels in small dorsal root ganglion neurons and modulate the response to pain. J Neurosci 2006 , 26:79847994.

18. Malhotra JD, Kazen-Gillespie K, Hortsch M, Isom LL: Sodium channel beta subunits mediate homophilic cell adhesion and recruit ankyrin to points of cell-cell contact. J Biol Chem 2000, 275:11383-11388.

19. Davis TH, Chen C, Isom LL: Sodium channel beta1 subunits promote neurite outgrowth in cerebellar granule neurons. J Biol Chem 2004, 279:51424-51432.

20. Brackenbury WJ, Davis TH, Chen C, Slat EA, Detrow MJ, Dickendesher TL, Ranscht B, Isom LL: Voltage-gated Na+ channel beta1 subunit-mediated neurite outgrowth requires Fyn kinase and contributes to postnatal CNS development in vivo. J Neurosci 2008, 28:3246-3256.

21. Kim DY, Carey BW, Wang H, Ingano LAM, Binshtok AM, Wertz MH, Pettingell WH, He P, Lee VM-Y, Woolf CJ, Kovacs DM: BACE1 regulates voltage-gated sodium channels and neuronal activity. Nat Cell Biol 2007, 9:755-764.

22. Kovacs DM, Gersbacher MT, Kim DY: Alzheimer's secretases regulate voltage-gated sodium channels. Neuroscience letters 2010, 486(2):68-72.

23. Sinha S, Anderson JP, Barbour R, Basi GS, Caccavello R, Davis D, Doan M, Dovey HF, Frigon N, Hong J, et al: Purification and cloning of amyloid precursor protein beta-secretase from human brain. Nature 1999, 402:537-540.

24. Turner RT, Koelsch G, Hong L, Castanheira P. Ermolieff J, Ghosh AK, Tang J, Castenheira P, Ghosh A: Subsite specificity of memapsin 2 (betasecretase): implications for inhibitor design. Biochemistry 2001 40:10001-10006.

25. Schlondorff J, Blobel CP: Metalloprotease-disintegrins: modular proteins capable of promoting cell-cell interactions and triggering signals by protein-ectodomain shedding. J Cell Sci 1999, 112(Pt 21):3603-3617.

26. Fukumoto H, Cheung BS, Hyman BT, Irizarry MC: Beta-secretase protein and activity are increased in the neocortex in Alzheimer disease. Arch Neurol 2002, 59:1381-1389.

27. Tyler SJ, Dawbarn D, Wilcock GK, Allen SJ: alpha- and beta-secretase: profound changes in Alzheimer's disease. Biochem Biophys Res Commun 2002, 299:373-376

28. Yang $L-B$, Lindholm $K$, Yan $R$, Citron $M$, Xia W, Yang X-L, Beach T, Sue L, Wong PC, Price $D$, et al: Elevated beta-secretase expression and enzymatic activity detected in sporadic Alzheimer disease. Nat Med 2003, 9:3-4. 
29. Loane DJ, Pocivavsek A, Moussa CE-H, Thompson R, Matsuoka Y, Faden Al, Rebeck GW, Burns MP: Amyloid precursor protein secretases as

therapeutic targets for traumatic brain injury. Nat Med 2009, 15:377-379.

30. Wen Y, Onyewuchi O, Yang S, Liu R, Simpkins JW: Increased beta-secretase activity and expression in rats following transient cerebral ischemia. Brain Res 2004, 1009:1-8.

31. Guglielmotto M, Aragno M, Autelli R, Giliberto L, Novo E, Colombatto $S$, Danni O, Parola M, Smith MA, Perry G, et al: The up-regulation of BACE1 mediated by hypoxia and ischemic injury: role of oxidative stress and HIF1alpha. J Neurochem 2009, 108:1045-1056.

32. Tesco G, Koh YH, Kang EL, Cameron AN, Das S, Sena-Esteves M, Hiltunen M, Yang S-H, Zhong Z, Shen Y, et al: Depletion of GGA3 stabilizes BACE and enhances beta-secretase activity. Neuron 2007, 54:721-737.

doi:10.1186/1750-1326-5-61

Cite this article as: Gersbacher et al:: Identification of BACE1 cleavage sites in human voltage-gated sodium channel beta 2 subunit. Molecular Neurodegeneration 2010 5:61.

\section{Submit your next manuscript to BioMed Central} and take full advantage of:

- Convenient online submission

- Thorough peer review

- No space constraints or color figure charges

- Immediate publication on acceptance

- Inclusion in PubMed, CAS, Scopus and Google Scholar

- Research which is freely available for redistribution

Submit your manuscript at www.biomedcentral.com/submit
C Biomed Central 